\title{
The Immunomodulation of Mangiferin on the Proliferation and Interleukin-2 Receptors Expression of in Vitro Culture of T lymphocytes Derived from Mammary Tumor Bearing Mice
}

\author{
Supri Irianti Handayani \\ Department of Anatomical Pathology, Faculty of Medicine, Universitas Indonesia \\ PO Box 1356, Salemba Raya 6 Jakarta 10430, Indonesia \\ Tel: 62-213-190-5888 E-mail: supri.handayani@yahoo.com \\ Kusmardi (Corresponding author) \\ Dept. of Anatomical Pathology, Faculty of Medicine, Universitas Indonesia \\ PO Box 1356, Salemba Raya 6 Jakarta 10430, Indonesia \\ Tel: 62-213-190-5888 E-mail: kusmardi.ms@ui.ac.id \\ Aryo Tedjo \\ Dept. of Medical Chemistry, Faculty of Medicine, Universitas Indonesia \\ PO Box 1356, Salemba Raya 6 Jakarta 10430, Indonesia \\ Tel: 62-213-193-0302 E-mail: aryo.tedjo@ui.ac.id
}

Received: October 18, 2014 Accepted: February 28, 2015 Published: March 18, 2015

Doi: 10.5296/jab.v3n2.6423 URL: http://dx.doi.org/10.5296/jab.v3n2.6423

\begin{abstract}
The development of a tumor has a strong relationship with cellular immunity mediated by $\mathrm{T}$ lymphocytes. Some research showed that mangiferin can increase host immunity but its scientific base was still unclear. The purpose of this study was to explain the role of mangiferin as an immunostimulator on in vitro $\mathrm{T}$ lymphocytes culture of mammary tumor bearing mice. $\mathrm{T}$
\end{abstract}


lymphocytes were isolated from the spleen of mice after two weeks of mammary tumor transplantation. The isolation was performed by using sterile nylon net and passed through nylon wool. Isolated T lymphocytes were cultured in vitro on RPMI 1640 medium. The culture of T lymphocytes was divided into three groups containing 5, 25 and $50 \mathrm{mg} / \mathrm{L}$ of mangiferin, and a control group (RPMI medium). The proportion of T lymphocytes and IL-2R $\alpha$ (CD25) expressed $\mathrm{T}$ cells were evaluated using immunoflouorescens techniques after one and three days of lymphocytes cultures. Our study showed that 5,25 and $50 \mathrm{mg} / \mathrm{L}$ mangiferin was effective to enhance IL-2R $\alpha$ (CD25) on $\mathrm{T}$ lymphocytes culture and $\mathrm{T}$ lymphocytes prolifferation.

Keywords: T lymphocytes, Interleukin-2 receptors, Mouse mammary tumor, Mangiferin

\section{Introduction}

Breast cancer is a malignant disease that affects women, including women in Indonesia. Of all malignant disease that attacks the Indonesian women, breast cancer ranks second $(28.03 \%)$, slightly below the cervical cancer (28.16\%). Treatment and management of breast cancer patients is quite complicated and expensive. In an effort to find ways of treatment with the potential use of natural ingredients Indonesia, needs to be done comprehensive research into the molecular level by studying the interactions between cells involved in the healing process (Prestwich et al., 2008; deVisser et al., 2006).

The treatment was complicated for people with breast cancer, also associated with the immune system because as general malignant disease associated with poor immunologic surveillance of patients. A discussion of immunologic surveillance can not be separated from the discussion of the role of T lymphocytes (Vesely et al., 2011; Grivennikov et al., 2010).

The Immune response was the result of interaction between antigen with immunocompetent cells, including their mediators. Lymphocytes are the basic units due to the formation of the immune response is able to differentiate into other series, as well as play a role in recognizing at once react with antigens (Macchetti et al., 2006).

$\mathrm{T}$ lymphocytes can act as effectors in the immune response, but can also act as regulators of the immune response because of its ability to influence the activity of other immunocompetent cells through the release of lymphokines. T-helper lymphocytes (Th) and T-suppressor (Ts) affects the production of immunoglobulin by B lymphocytes.

After antigen contact with B lymphocytes proliferate later, partially differentiate into plasma cells that synthesize and secrete immunoglobulin, and some B lymphocytes into memory Curigliano et al., 2011).

In the in vivo processing of tumor antigens would involve both humoral and cellular immune responses. Effector components of the immune system which has the ability to react with tumor cells are: $\mathrm{T}$ lymphocytes, antibody-dependent cellular cytotoxicity (ADCC), natural killer (NK) cells and macrophages. To perform these functions properly, they need to go through the process of $\mathrm{T}$ lymphocyte activation previously. $\mathrm{T}$ lymphocyte activation occurs due to the introduction of antigens that have been processed by macrophages as antigen presenting cells (APC). In addition to the role of antigen in activating $\mathrm{T}$ lymphocytes, an 
immunostimulator also can play a role in this process (Sheu et al., 2008; Gooden et al., 2011).

The immunostimulator contained in natural materials, was researched and developed as an alternative cancer treatment. One alternative natural materials that can be explored was the mango leaves. Mango fruit contains mangiferin and other polyphenols. Both mangiferin and polyphenols contained in mango fruit promote to study its use for alternative cancer therapies. The potential report of mangiferin as a potent antioxidant in breaking free radicals caused by the administration of carcinogenic compounds (Chattopadhyay et al., 1987).

This study showed that administration of mangiferin extracted from mango fruit using water and ethanol solvents on the in vitro culture can increase the expression of interleukin-2 receptors on $\mathrm{T}$ lymphocytes and $\mathrm{T}$ lymphocytes prolifferation

\section{Methods}

\subsection{The Extraction of Mangiferin}

A total of 150 grams of rice dumplings fresh mango fruit peel was dried and pulverized extracted by maceration using ethanol or water $1500 \mathrm{ml}$ (1: 10), performed maceration for 24 hours at room temperature. The filtrate was filtered and then concentrated by rotary vacuum evaporator at a temperature of $50 \mathrm{oC}$. Viscous filtrate were then dried by the freeze drier to remove residual solvent remaining. Mangiferin isolation method refers to a method performed Garcia et al. (2002). A total of $10 \mathrm{~g}$ of dry powder of mango fruit peel (Mangifera foetida Lour) was placed in Soxhlet with petroleum ether (60-800C) for 12 hours. The plant material without fat then extracted with ethanol by means of reflux for 16 hours, then removed again defatted with petroleum ether and crystallized with ethyl acetate (Morgan \& Darling, 1993).

\subsection{The Experimental Animals}

The experimental animals used were mice strain C3H, 4 months old, weighing 20-25 g.

\subsection{Treatment on Mangiferin}

Testing the test solutions were divided into four groups with three repetitions.

Group I (control group): suspension lymphocyte $1 \times 10^{6}$ cells / $\mathrm{ml}$ of $200 \mathrm{~mL}$ in RPMI medium. Group II: lymphocyte cell suspension $1 \times 10^{6}$ cells / $\mathrm{mL}$ of $180 \mathrm{~mL}$ in RPMI medium and $20 \mu \mathrm{l}$ of mangiferin $5 \mathrm{mg} / \mathrm{L}$. Group III: lymphocyte cell suspension $1 \times 10^{6}$ cells / $\mathrm{mL}$ of $180 \mathrm{~mL}$ in RPMI medium and $20 \mu \mathrm{l}$ mangiferin $25 \mathrm{mg} / \mathrm{L}$. Group IV: lymphocyte cell suspension $1 \times 106$ cells / $\mathrm{mL}$ of $180 \mathrm{~mL}$ in RPMI medium and $20 \mu \mathrm{l}$ mangiferin $50 \mathrm{mg} / \mathrm{L}$. Each group was filled into the microwell and incubated in $5 \%$ carbon dioxide incubator at a temperature of $37^{\circ} \mathrm{C}$. Observations were made for 2 times (day-1 and day-3) after treatment acetate (Morgan \& Darling, 1993).

\subsection{T lymphocytes Cultures}

$\mathrm{T}$ lymphocytes as effector cells isolated from the spleen of normal and mamary tumor bearing mice, 2 weeks posttumor transplantation. The mice spleen placed at $60 \mathrm{~mm}$ sterile dish containing $5 \mathrm{ml}$ of serum-free medium. To obtain cell suspensions of lymphocytes, cells were 


\section{Macrothink}

passed on sterile nylon net. Ammonium chloride buffer was used for lysis of erythrocytes.

T lymphocytes enrichment was done by passing the cell suspension on nylon wool columns. First, nylon wool (Biotest) soaked in $2 \mathrm{M} \mathrm{HCl}$, washed with flowing aquadest 5-6 times and dried. Nylon wool fibers filled into polyethylene plastic syringe (Terumo). Each $0.6 \mathrm{~g}$ of nylon wool, loaded on a $10 \mathrm{ml}$ syringe as a column of spleen cell suspension or $0.3 \mathrm{~g}$ of nylon wool, loaded on a $5 \mathrm{ml}$ syringe column of macrophage suspension.

The column was preincubated with RPMI 1640 medium containing 5\% fetal bovine serum (FBS) two times the volume of the syringe. Resuspended cell suspension into $5.10^{6}$ cells $/ \mathrm{ml}$. The cell suspension was dripped through the column and incubated $60 \mathrm{~min}$ at $37{ }^{\circ} \mathrm{C}$. Lymphocytes elution that do not bind to the column was done by adding the medium to the column as much as one-time syringe volume. T lymphocytes eluent were washed 2 times by centrifugation $200 \mathrm{~g}$ for 5 minuttes.

The cell suspensions were cultured in RPMI medium containing $10 \%$ fetal calf serum (FCS), 2 $\mathrm{mM}$ L-glutamine, $100 \mathrm{U} / \mathrm{mL}$ penicillin, $100 \mathrm{mg} / \mathrm{mL}$ streptomycin, and $50 \mathrm{mM}$ 2-mercaptoethanol. Mangiferin extract with different doses selected were $100 \mathrm{ul}$ added to each culture well of T lymphocytes (Garcia et al., 2002).

\subsection{The Expression of IL-2 Receptor Alpha Evaluation}

The $\mathrm{CD}^{+}$T-lymphocyte activity was measured by the expression of IL-2 receptor alpha (IL-R $\alpha$ ) existing in 24, 48 and 72 hours in vitro culture of spleen T lymphocytes of mammary tumor bearing mice by using immunofluorescence techniques.

\subsection{Analysis of Data}

To determine differences between the groups was performed one-way ANOVA followed by Tukey test.

\section{Result and Discussion}

\subsection{T Limphocyte Prolifferation}

In vitro culture or $\mathrm{T}$ lymphocytes derived from mammary tumor bearing mice was cultured on microwell plate (Figure 1A) and prolifferation was count on haemocytometer (Figure 1B). Figure 2 showed an increased number of $\mathrm{T}$ lymphocytes per $\mathrm{ml}$ with mangiferin administration of a dose of 5,25 and $50 \mathrm{mg} / \mathrm{L}$. According to analysis of variance indicated that there was a significant difference $(p=0.02)$ between treatments groups ang control group. The tests were followed by Tukey HSD test, showed that the significant difference between the control group with other groups. That means the provision of mangiferin impact on increasing the number of $\mathrm{T}$ lymphocytes in cell culture either on the first day and on the third day. 

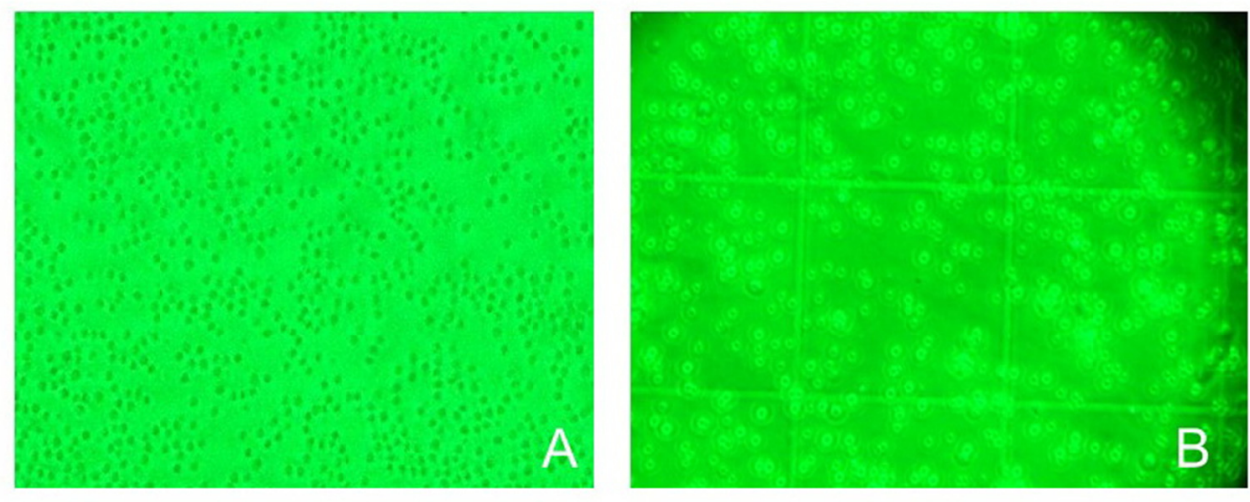

Figure 1. T lymphocytes derived from cultures on days one and three on the glass object (A, $40 \times)$ and hemocytometer $(\mathrm{B}, 100 \times)$ was observed using phase contrast microscopy

The test is also shown that administration of mangiferin with a dose of 5,25 and $50 \mathrm{mg} / \mathrm{L} \mathrm{did}$ not result in increased proliferation, although from the graph shown in Figure 2 showed an increase with increasing dose, especially on the third day prolifferation. The opposite occurs on the first day which showed a slight decrease as showed in Figure 2, although statistically not showed significant differences.

Thus, administration of mangiferin in cultured lymphocytes isolated from the spleen of mammary tumor bearing mice either in the first or third day resulted in increased proliferation, but it does not showed dependency on the dose (dose-dependent). This is more common in studies using natural extracts, where the active compound is not known. Further studies were extrapolated at doses between $5 \mathrm{mg} / \mathrm{L}$ to $25 \mathrm{mg} / \mathrm{L}$ is useful to determine the optimum dose that can increase the number of $\mathrm{T}$ lymphocytes.

The results of this study, in line with previous studies, which linked the provision of mangiferin with increased immune response, using either experimental animals or in vitro using cell lines that most of the results of these studies resulted in an increase in the specific immune response mediated by $\mathrm{T}$ lymphocytes and lymphocytes in general, especially, as well as nonspecific immune system include macrophages, polymorphonuclear cells, and dendritic cells. This study was also in line with research that showed the relationship between the administration of mangiferin with the ability of cells that act as antigen-presenting cells (APC) in presenting antigens to T helper lymphocytes (Hernandes et al., 2007; Sanchez et al., 2000; Garido et al., 2004a; Garido et al., 2004b; Garcia et al., 2003). 


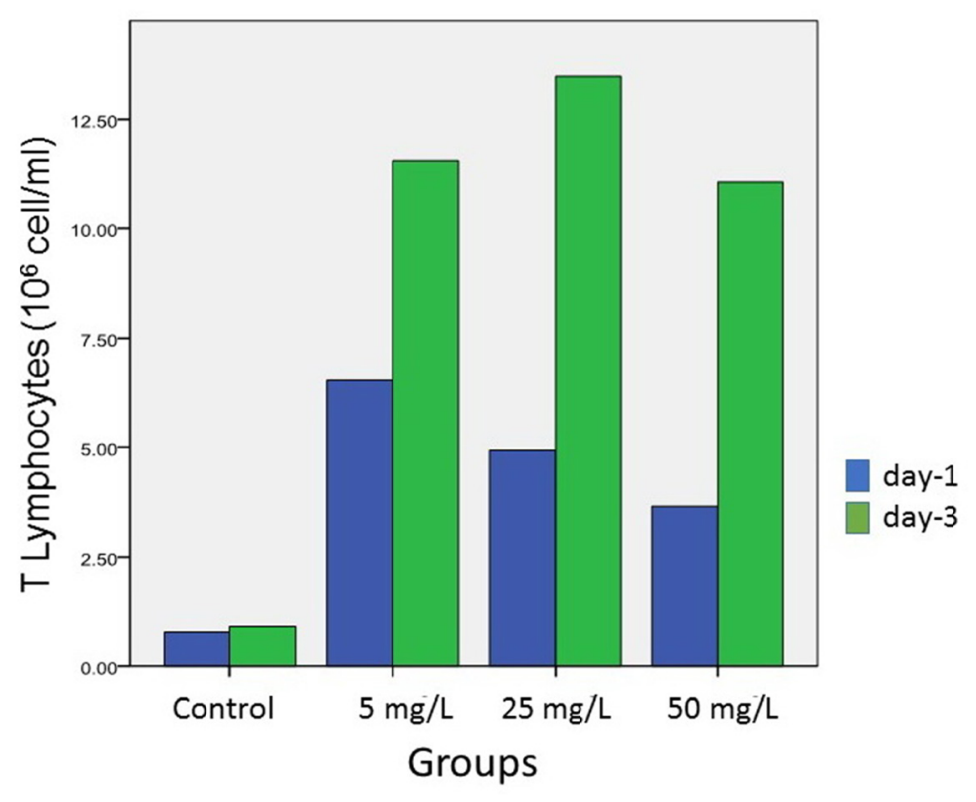

Figure 2. The number of T lymphocytes $\left(10^{6}\right.$ cells $\left./ \mathrm{ml}\right)$ of four groups after 1 and 3 days administration of mangiferin

\subsection{The expression of Interleukin-2 Receptor on T lymphocytes}

By indirect immunofluorescence staining using mouse anti-interleukin-2 receptor, as shown in Figure 3, showed the interleukin-2 receptor expressed on the cell membrane of $\mathrm{T}$ lymphocytes.
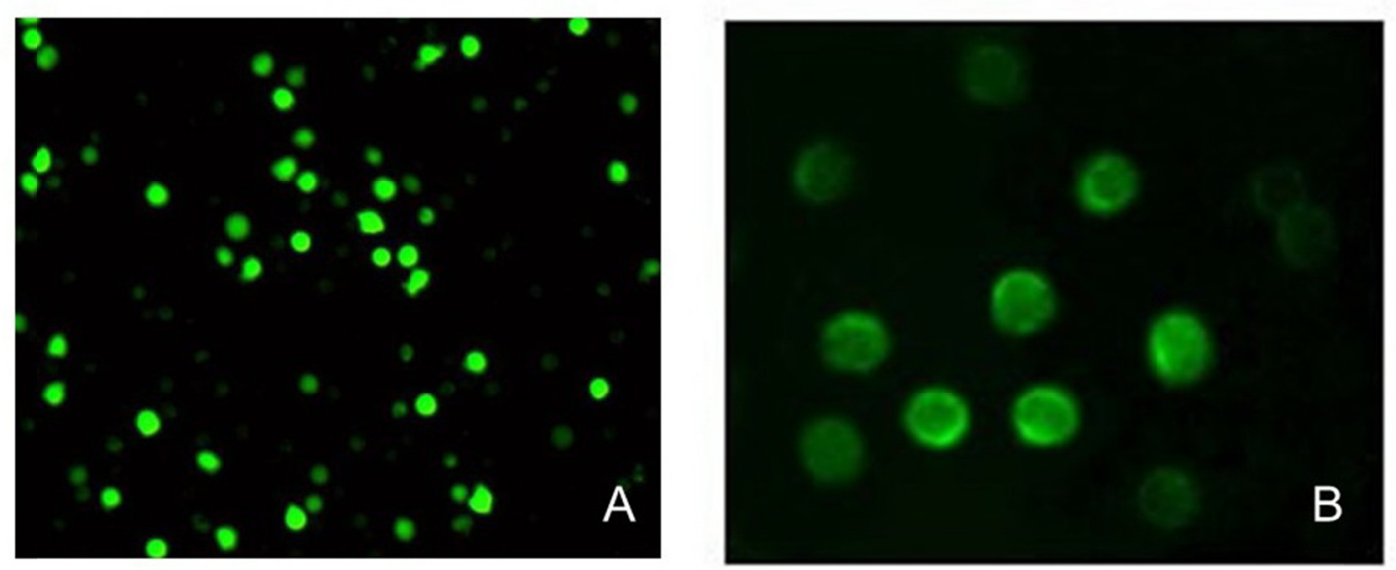

Figure 3. Direct immunoflourescens staining with rabbit anti-mouse interleukin-2 receptors antibody on $\mathrm{T}$ lymphocytes derived from the spleen of mammary tumor bearing mice, of dosage group of $25 \mathrm{mg} / \mathrm{L}$ (A, strong expression (3+), magnification 100×) and $50 \mathrm{mg} / \mathrm{L}(\mathrm{B}$, moderate expression (2+), magnification $400 \times$ ) 


\section{Macrothink

With Kriskal-Wallis test indicated there were significant differences in the interleukin-2 receptor expression between the control group with both dose groups of mangiferin 5, 25 or $50 \mathrm{mg} / \mathrm{L}$ in T lymphocytes cultured either one day or three days. This was also showed by Figure 4, which suggests that in all three treatment groups, indicating that the same bar chart, the moderate to strong expression in cultured three days between weak and strong until one day old cultures. It was thus gives results consistent with the increased proliferation of $\mathrm{T}$ lymphocytes.

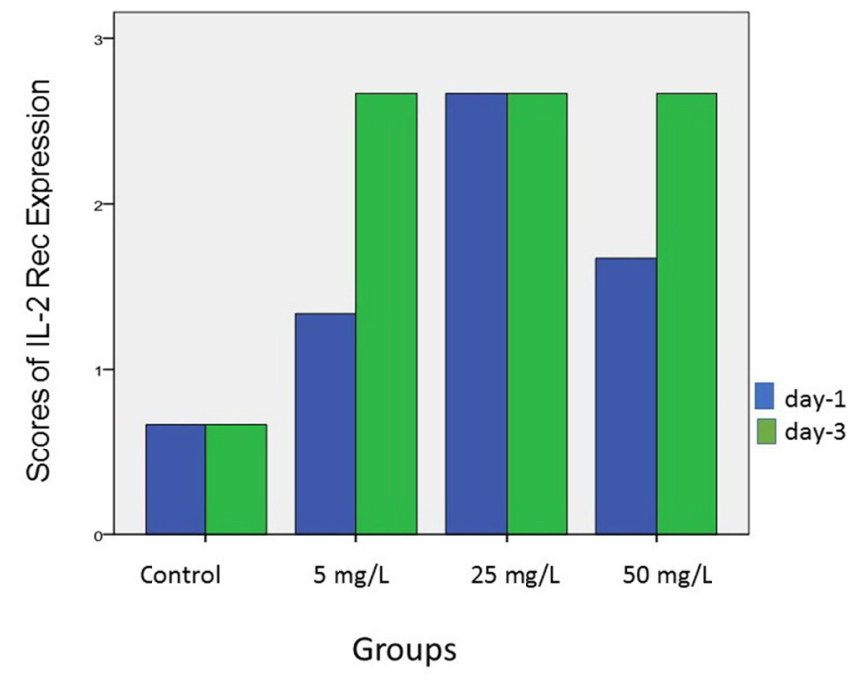

Figure 4. Expression of interleukin-2 receptor (IL-2 rec) on T lymphocytes after administration of mangiferin 1 and 3 days using immunofluorescence ( 0 : negative, 1 : weak, 2 : moderate and 3: strong)

To see the relationship between the prolifferation of $\mathrm{T}$ lymphocytes with interleukin-2 receptor expression was analyzed using correlation Kendall test. According to the test, there was a correlation between the prolifferation of $\mathrm{T}$ lymphocytes with interleukin-2 receptor expression on $\mathrm{T}$ lymphocytes. This fact illustrates that proliferation was enhanced with an increase in interleukin-2 receptor. According to many studies presented that the activities of $T$ lymphocytes as effector function, characterized by the increased expression of the interleukin-2 receptor alpha (Muruganandan et al., 2005a; Muruganandan et al., 2005b; Agarwala et al., 2012; Viswanadh et al., 2010).

\section{Conclusion}

Administration of mangiferin in cultured lymphocytes isolated from the spleen of mammary tumor bearing mice either in the first or third day resulted in increased proliferation, but it was not dose-dependent. There was a correlation between the prolifferation of lymphocytes with interleukin-2 receptor expression on T lymphocytes. 


\section{Refferences}

Agarwala, S., Rao, B. N., Mudholkar, K., Bhuwania, R., \& Rao, B. S. (2012). Mangiferin, a Dietary Xanthone Protects Against Mercury-Induced Toxicity in HepG2 Cells. Environ Toxicol, 27(2), 117-127. http://dx.doi.org/10.1002/tox.20620

Chattopadhyay, U., Das, S., Guha, S., Ghosal, S. (1987). Activation of lymphocytes of normal and tumor bearing mice by mangiferin, a naturally occurring glucosylxanthone. Cancer Lett., 37(3), 293-9. http://dx.doi.org/10.1016/0304-3835(87)90114-5

Curigliano, G. (2011). Immunity and autoimmunity: revising the concepts of response to breast cancer. Breas, 20(supp 3), S71-S74. http://dx.doi.org/10.1016/S0960-9776(11)70298-3 de Visser, K. E., Eichten, A., \& Coussens, L. M. (2006). Paradoxical roles of the immune system during cancer development. Nat Rev Cancer, 6(1), 24-37. http://dx.doi.org/10.1038/nrc1782

García, D., Delgado, R., Ubeira, F. M., \& Leiro, J. (2002). Modulation of rat macrophage function by the Mangifera indica L. extracts Vimang and mangiferin. Int Immunopharmacol, 2(6), 797-806. http://dx.doi.org/10.1016/S1567-5769(02)00018-8

García, D., Leiro, J., Delgado, R., Sanmartín, M. L., \& Ubeira, F. M. (2003). Mangifera indica L. extract (Vimang) and mangiferin modulate mouse humoral immuneresponses. Phytother Res., 17(10), 1182-7. http://dx.doi.org/10.1002/ptr.1338

Garrido, G., Delgado, R., Lemus, Y., Rodríguez, J., García, D., \& Núñez-Sellés, A. J. (2004a). Protection against septic shock and suppression of tumor necrosis factor alpha and nitric oxide production on macrophages and microglia by a standard aqueous extract of Mangifera indica L. (VIMANG). Role of mangiferin isolated from the extract. Pharmacol Res, 50(2), 165-72. http://dx.doi.org/10.1016/j.phrs.2003.12.020

Garrido, G., González, D., Lemus, Y., García, D., Lodeiro, L., Quintero, G., ... Delgado, R. (2004b). In vivo and in vitro anti-inflammatory activity of Mangifera indica L. extract (VIMANG). Pharmacol Res., 50(2), 143-9. http://dx.doi.org/10.1016/j.phrs.2003.12.003

Gooden, M. J. M., de Bock, G. H., Leffers, N., Daemen, T., \& Nijman, H. W. (2011). The prognostic influence of tumour-infiltrating lymphocytes in cancer: a systematic review with meta-analysis. Br J Cancer, 105(1), 93-103. http://dx.doi.org/10.1038\%2Fbjc.2011.189

Grivennikov, S. I., Greten, F. R., \& Karin, M. (2010). Immunity, inflammation, and cancer. Cell, 140(6), 883-899. http://dx.doi.org/10.1016\%2Fj.cell.2010.01.025

Hernandez, P., Rodriguez, P. C., Delgado, R., \& Walczak, H. (2007). Protective effect of Mangifera indica $\mathrm{L}$. polyphenols on human $\mathrm{T}$ lymphocytes against activation-induced cell death. Pharmacol Res., 55(2), 167-73. http://dx.doi.org/10.1016/j.phrs.2006.11.004

Macchetti, A. H., Marana, H. R. C., Silva, J. S., de Andrade, J. M., Ribeiro-Silva, A., \& Bighetti, S. (2006). Tumor-infiltrating CD4+ T lymphocytes in early breast cancer reflect lymph node involvement. Clinics, 61(3), 203-208. http://dx.doi.org/10.1590/S1807-59322006000300004

Morgan, S. J., \& Darling, D. C. (1993). Animal Cell Culture (pp. 27-36). United Kingdom: Bios Scintific Publisher Limited. 


\section{Macrothink}

Muruganandan, S., Lal, J., \& Gupta, P. K. (2005a). Immunotherapeutic effects of mangiferin mediated by the inhibition of oxidative stress to activated lymphocytes, neutrophils and macrophages. Toxicol., 215(1-2), 57-68. http://dx.doi.org/10.1016/j.tox.2005.06.008

Muruganandan, S., Srinivasan, S. K., Gupta, P. K., \& Gupta, J. L. (2005b). Effect of mangiferin on hyperglycemia and atherogenicity in streptozotocin diabetic rats. $J$ Ethnopharmacol, 97, 497-501. http://dx.doi.org/10.1016/j.jep.2004.12.010

Sánchez, G. M., Re, L., Giuliani, A., Núñez-Sellés, A. J., Davison, G. P., \& León-Fernández, O. S. (2000). Protective effects of Mangifera indica L. extract, mangiferin and selected antioxidants against TPA-induced biomolecules oxidation and peritoneal macrophage activation in mice. Pharmacol Res., 42(6), 565-73. http://dx.doi.org/10.1006/phrs.2000.0727

Sheu, B., Kuo, W., Chen, R., Huang, S., Chang, K., \& Chow, S. (2008). Clinical significance of tumor-infiltrating lymphocytes in neoplastic progression and lymph node metastasis of human breast cancer. Breast., 17(6), 604-610. http://dx.doi.org/10.1016/j.breast.2008.06.001

Viswanadh, E. K., Rao, B. N., \& Rao, B. S. (2010). Antigenotoxic effect of mangiferin and changes in antioxidant enzyme levels of Swiss albino mice treated with cadmium chloride Hum Exp Toxicol., 29, 409-418. http://dx.doi.org/10.1177/0960327110361752

Prestwich, R. J., Errington, F., \& Hatfield, P. (2008). The immune system: is it relevant to cancer development, progression and treatment? Clin Oncol., 20(2), 101-112. http://dx.doi.org/10.1016/j.clon.2007.10.011

Vesely, M. D., Kershaw, M. H., Schreiber, R. D., \& Smyth, M. J. (2011). Natural innate and adaptive immunity to cancer. Ann Rev Immunol, 29, 235-271. http://dx.doi.org/10.1146/annurev-immunol-031210-101324

\section{Copyright Disclaimer}

Copyright reserved by the author(s).

This article is an open-access article distributed under the terms and conditions of the Creative Commons Attribution license (http://creativecommons.org/licenses/by/3.0/). 